\title{
ON THE ATTITUDE TO RISK AND THE DECISION-MAKING BEHAVIOR
}

\author{
Paul COCIOC ${ }^{\mathrm{a}, *}$ \\ a) Babeș-Bolyai University, Faculty of Economics and Business Administration, \\ Cluj-Napoca, Romania
}

Please cite this article as:

Article History:

Cocioc, P., 2017. On the attitude to risk and the decision- Received: 19 December 2016 making behavior. Review of Economic Studies and Research Virgil Madgearu, 10(1), pp.27-46.

Accepted: 1 April 2017

doi: 10.24193/RVM.2017.10.03.

Abstract: The paper is intended to be a synthesis of the general approaches on
economic risk and economic decisions under risk. Delimitation of the risk from
the uncertainty is based on Knight's views. Basically decisions are analyzed in
a conventional manner by using the expected utility hypothesis. The paradigm
is presented both historycal and critically from Bernoulli to von Neumann and
Morgenstern. It develops some ideas on the elements encountered in establishing
the minimal acceptable level of outcomes for risk-taking. The comments and
conclusions highlight certain limits on rationality in economic decision. Key words: risk; risk-aversion; uncertainty; decision-making; expected-utility hypothesis

JEL Classification: Do1; D11; D81

(C) 2017 Alma Mater Publishing House. All rights reserved.

* Corresponding author. E-mail address: paul.cocioc@econ.ubbcluj.ro. 


\section{References}

1. Arrow, K.J., 1965. The Theory of Risk Aversion in Aspects of the theory of risk-bearing. Helsinki: Yrjo Jahnssonin Saatio, pp.28-44. Reprint in Arrow, K.J. (1971). Essays in the Theory of Risk-Bearing. Chicago: Markham Publishing.

2. Bentham, J., 1789. An Introduction to the Principles of Morals and Legislation. Oxford: Claredon Press [reprint 1907], Library of Economics and liberty [online] available at: http://www.econlib. org/library/Bentham/bnthPML.html; [accessed 21 March 2016].

3. Bernoulli, D., 1954. Exposition of a New Theory on the Measurement of Risk (1738), Translated into English by L. Sommers, Econometrica, 22(1), pp.23-36. http://dx.doi.org/10.2307/1909829.

4. Clitan, G., 2002. Pragmatică şi postmodernism. Despre jocul raţionalităţii şi presupoziţiilor în abordarea metafilosofică a culturii. Timișoara: Solness.

5. Cocioc, P., 2000. Fundamente ale ștïnței economice. Cluj-Napoca: Risoprint.

6. Eeckhoudt, L.,2012. Beyond Risk Aversion: Why, How and What's Next?. The Geneva Risk and Insurance Review, 37(2), pp.141-155. http://dx.doi.org/10.1057/grir.2012.1.

7. Eeckhoudt, L., Gollier, C. and Schlesinger, H., 2005. Economic and financial decisions under risk. Princeton and Oxford: Princeton University Press.

8. Eeckhoudt, L., 2014. Arrow-Pratt's risk aversion: 50 years later. Journees Internationales du risques. Retrived from: http:// iriaf.univ-poitiers.fr/images/medias/fichier/arrow-pratt-50years_1403101635925-pdf. [Accessed 20 Nov. 2016].

9. Friedman, M. and Savage, L., 1948. The Utility Analysis of Choices Involving Risk. Journal of Political Economy, 56(4), pp.279-304. http://dx.doi.org/10.1086/256692.

10. Geller, D., 2013. Money Anxiety: How financial uncertainty changes consumer behavior and the economy. Sarasota: First Edition Design Publishing.

11. Grant, H. and Higgins, T.E., 2013. Do You Play to Win or to Not Lose?. Harvard Business Review, 2. Retrieved from: https://hbr. org/2013/o3/do-you-play-to-win-or-to-not-lose [Accessed 20 November 2016]. 
12. Hillson, D. and Murray-Webster, R., 2007. Understanding and Managing Risk Attitude. $2^{\text {nd }}$ ed. Aldershot: Gower.

13. Kahneman, D. and Tversky, A., 1979. Prospect Theory: An Analysis of Decision under Risk. Econometrica, 47(2), pp.263-292. http:// dx.doi.org/10.2307/1914185.

14. Keynes, J.M., 1936. The General Theory of Employment, Interest and Money. London: Macmillan.

15. Knight, F.H., 1921. Risk, Uncertainty and Profit. Boston: Houghton Mifflin [reprint 1933].

16. Maliţa, M. and Zidăroiu, C., 1980. Incertitudine şi decizie, vol.1, Bucureşti: Editura Ştiinţifică şi Enciclopedică.

17. Machina, M.J., 1987. Choice Under Uncertainty: Problems Solved and Unsolved. The Journal of Economic Perspectives, 1(1), pp.121-154. http://dx.doi.org/10.1257/jep.1.1.121.

18. Negoescu, G., 1995. Risc și incertitudine în economia de piață. Galaţi: Alter-Ego Cristian.

19. Neumann, J. von and Morgenstern, O., 1944. Theory of Games and Economic Behavior. Princeton: Princeton University Press.

20. Pratt, J., 1964. Risk Aversion in the Small and in the Large. Econometrica, 32(1/2), pp.122-136. http://dx.doi. org/10.2307/1913738.

21. Rothschild, M. and Stiglitz, J.E., 1971. Increasing risk II: Its Economic consequences. Journal of Economic Theory, 3(1), pp.66-84. https:// doi.org/10.1016/0022-0531(71)90034-2.

22. Samuelson, P.A., 1977. St. Petersburg Paradoxes: Defanged, Dissected, and Historically Described. Journal of Economic Literature, 15(1), pp.24-55.

23. Tversky, A. and Kahneman, D., 1992. Advances in Prospect Theory: Cumulative Representation of Uncertainty. Journal of Risk and Uncertainty, 5(4), pp.297-323. http://dx.doi.org/10.1007/ BFoo122574.

24. Weber, M., 1904. Essais sur la théorie de la science. Premier essai: "L'objectivité de la connaissance dans les sciences et la politique sociales”. [e-book] Université du Québec à Chicoutimi. Available at: http://classiques.uqac.ca/classiques/Weber/essais_theorie_science/ Essais_science_1.pdf [Accessed 20 February 2016].

25. Weber, M., 1913. Essais sur la théorie de la science. Troisième essai: "Essai sur quelques catégories de la sociologie compréhensive". [e-book] Université du Québec à Chicoutimi. available at: http:// 
classiques.uqac.ca/classiques/Weber/essais_theorie_science/ Essais_science_3.pdf [Accessed 20 February 2016].

26. Correspondence of Nicolas Bernoulli concerning the St. Petersburg Game. [Translated by Pulskamp, R.J., 2013. Department of Mathematics \& Computer Science. Xavier University, Cincinnati] [online] Available at: http://cerebro.xu.edu/math/Sources/ NBernoulli/correspondence_petersburg_game.pdf [Accessed 20 February 2016]. 